Residual Austenite and 1ts effect on Practure Toughness of Coarse-Grained Heat-Affected zone of H.S.L.A. Steels.

R. Talliard, J. Poct, Métaliurgie Physique, Université de Lille I, Villenouve d'Ascq, France.

P. Verrier, T. Maurickx, Centre de Recherches et do Développements Métallurgiques, Sollac, Dunkerque, Prance.

\title{
Introduction
}

Structural steels are used in ever more severo environment. In order to overcome this difficulty, the steels must satisfy roqulrements in the base metal and in the weldments. One of the most critical propertles 18 a high toughness, at low temperatures. In the coarse-gralned heat-affected zone (H.A.2.). The aim of the present paper 18 to investigate the effect of the microstructure, and more particularly of the residual austenite content. on the H.A.Z. reallience in low carbon microalloyed steels. By the way. the volume fraction and composition of the austenite are determined by $x$-ray diffractometry and Mossbauer spectronetry.

Materials and experimental procedures

The base composition of the seven mlcroalloyed steel specimens 180.1 wt $C_{1} 1.5 \mathrm{wt} \mathrm{Mn}, 0.4 \mathrm{Wt} \mathrm{NL}$ and $0.050 \mathrm{wt} \mathrm{Al}$. Table I exhiblta the composition varlations between the alloys. The only Ti-mlcroalloyed steels VI and VII were produced using a controlled rolling and accelerated cooling process. The steels I to $V$ arlse from controlled rolling and normalisation treatments. It 18 worth noting that they differ by their level in microalloying additions. Steel I contains $V$. Nb and $T i$ wheroas steel II displays $\mathrm{Nb}$ and $\mathrm{Tl}$ and steol III only Nb. Alloys IV and $V$ are only $T I-m i c r o a l l o y e d$.

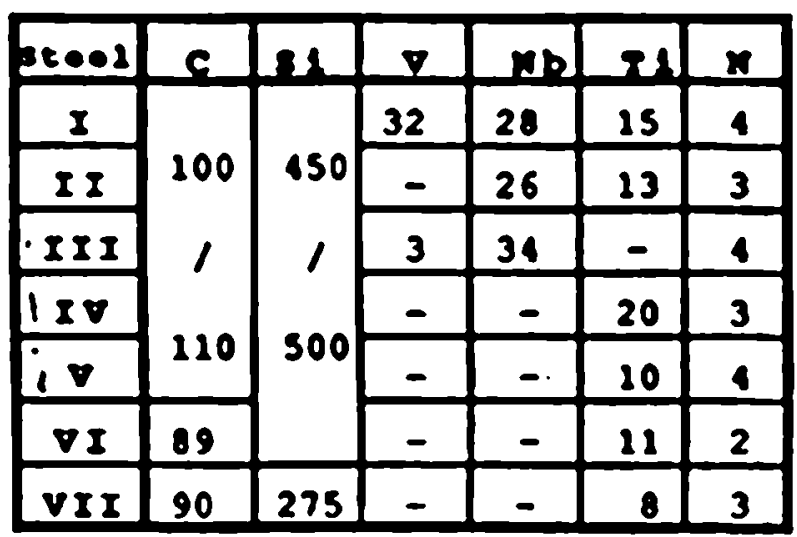

Tab, Li Chemical analysis $\left(10^{-3}\right.$ wt $)$ of the steels plates.

Tho steels were investigated after simulated H.A.2. thermal cycles. These heat treatments were applied using a Gleeble 
1500 thermomechanical simulator. The cycles wore defined by a $100 \mathrm{~K} . \mathrm{s}^{-1}$ heating rate up to $1623 \mathrm{~K}\left(1350^{\circ} \mathrm{C}\right)$ and by a cooling $t$ imc $(\Delta t)$ between $973 \mathrm{~K}\left(700^{\circ} \mathrm{C}\right)$ and $573 \mathrm{~K}\left(300^{\circ} \mathrm{C}\right)$. The coollng rate depends on welding energy. For the oteels II, IV and $V$ the $\Delta t$ is equal to $300 \mathrm{~s}\left(10 \mathrm{~kJ} \cdot \mathrm{mm}^{-1}\right)$ whereas $1 \mathrm{t}$ is ranglng Irom 10 to 300 s $\left(0.3 \mathrm{~kJ} . \mathrm{mm}^{-1}\right.$ to $\left.10 \mathrm{~kJ} . \mathrm{mm}^{-1}\right)$ for the other alloys. The width of the simulated H.A.2. is close to $5 \mathrm{~mm}$.

The microstructural analyses were performed by X-ray diffractometry. thin foll (45 um) transmission Mossbauer spectrometry. light, scanning and thin foll transmission electron microscopy.

The mechanical propertios were characterized by instrumonted Charpy $V$ toughness and C.T.O.D. tests. These experiments were carried out with specimens which were taken in transverse direction and close to the plate surfaces. Dimensions of the C.T.O.D. samples were $20 \times 10 \times 100 \mathrm{~mm}$ with total notch and crack length of 10 including 2 latigue crack.

Results and discussion
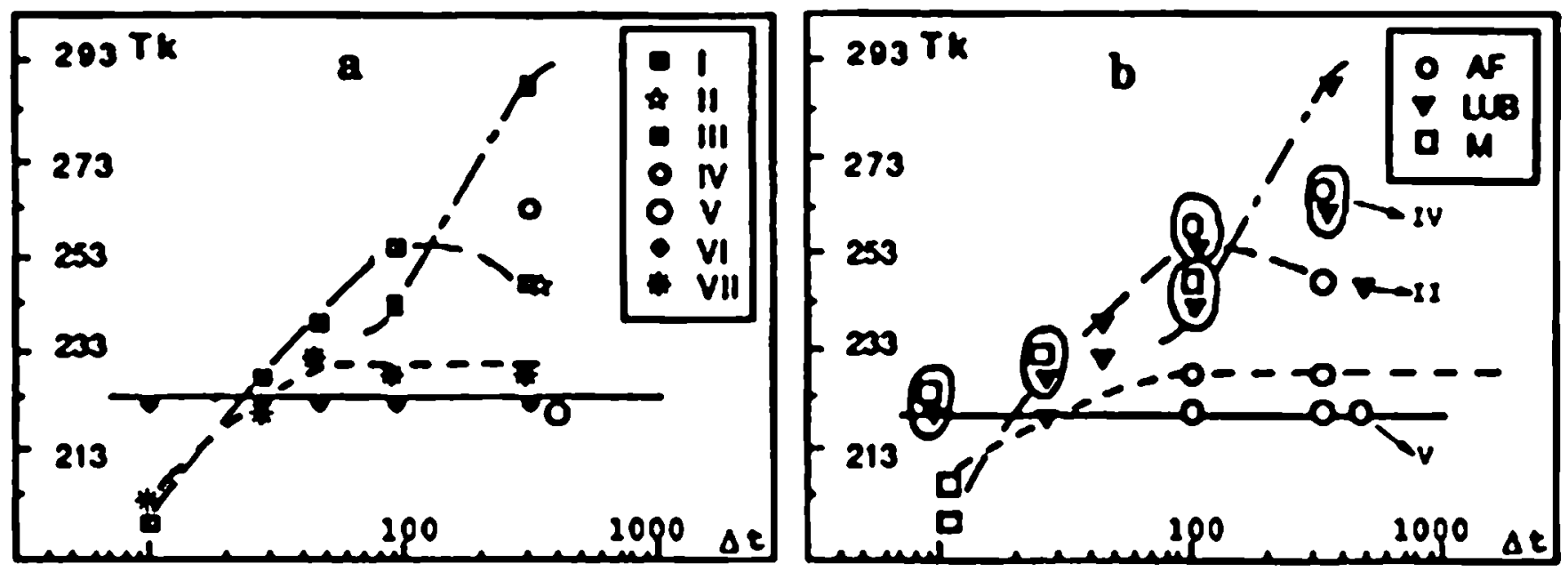

P1g. 1: Evolution of $T_{R}$ with ot : a) Experimental data, b) correIation with mlcrostructure (M: martensite, L.U.B.: lath upper bainite. A.F. : acicular feritel

P1g. I exhibits the rolationship between the $28 \mathrm{~J}$ Charpy $V$ transition terperatures $\left(T_{K}\right)$ of the materials and their heat treatment. It 18 worth noting that, except for steel VI for whlch $T_{K}$ remalns constant, $T_{K}$ increases in general way with the welding energy. Furthermore, the chemical composition dependence of $T_{K} 18$ noticeable at all $\Delta t$. These features are explained by the H.A.z. mlcrostructure differences.

\section{H.A.2. microstructure}

The percentages of H.A.2. phases contents are collected in Tab. 2. Representative mlcrographs of the varlous phases have already been published $(1-4)$. With the increment of $\Delta t$, the microstructuro changes from martensite, to lower bainite, lath uppor bainito and finally to a mixture of aclcular and proeutec- 
told ferrite. The differences in proeutectoid ferrite, lath upper bainite and acicular ferrite volume fractions among the varlous alloys pertain to their levels of nitrogen and of microalloyling additions (V,Ti,Nb) (2-3). Morcover, and as illustratcd by Fig. 2. transmission electron microscopy shows the prescnce of "Martensite-nustenite-Carbide" (M.A.C.) second phases in upper bainite.

\begin{tabular}{|c|c|c|c|c|c|c|c|c|c|c|c|c|c|c|c|c|c|c|c|}
\hline & \multicolumn{4}{|c|}{1} & 11 & \multicolumn{4}{|c|}{111} & IV & $v$ & \multicolumn{4}{|c|}{ VI } & \multicolumn{4}{|c|}{ VII } \\
\hline$\Delta t$ & 10 & 30 & 100 & 300 & 300 & 10 & 30 & 100 & 300 & 300 & 300 & 10 & 30 & 100 & 300 & 10 & 30 & 200 & 300 \\
\hline $\begin{array}{l}n \\
200 \\
17 \\
18\end{array}$ & $\begin{array}{l}10 \\
30 \\
! \\
\square\end{array}$ & $\begin{array}{l}50 \\
\text { so } \\
- \\
-\end{array}$ & $\begin{array}{l}\text { so } \\
\text { so } \\
\text { s }\end{array}$ & $\begin{array}{l}\text { s } \\
\text { ss } \\
30\end{array}$ & $\begin{array}{l}- \\
\text { is } \\
\text { is }\end{array}$ & $\begin{array}{c}100 \\
- \\
- \\
-\end{array}$ & $\begin{array}{r}95 \\
5 \\
- \\
-\end{array}$ & $\begin{array}{c}\text { so } \\
\text { so } \\
- \\
-\end{array}$ & $\begin{array}{c}100 \\
-\end{array}$ & $\begin{array}{l}\text { is } \\
\text { is } \\
10\end{array}$ & $\begin{array}{l}- \\
13 \\
13 \\
10\end{array}$ & $\begin{array}{l}\text { ss } \\
\text { is } \\
- \\
-\end{array}$ & $\begin{array}{r}35 \\
60 \\
- \\
3\end{array}$ & $\begin{array}{l}- \\
33 \\
30 \\
15\end{array}$ & $\begin{array}{l}- \\
20 \\
60 \\
20\end{array}$ & $\begin{array}{r}10 \\
20 \\
- \\
-\end{array}$ & $\begin{array}{r}55 \\
43 \\
- \\
-\end{array}$ & $\begin{array}{l}- \\
\text { ss } \\
60 \\
5\end{array}$ & $\begin{array}{l}- \\
10 \\
10\end{array}$ \\
\hline
\end{tabular}

Tab. 2: Optical evaluation of H.A.2. phases amounts (in vol. 1 ). P.P.: proeutectold ferrite
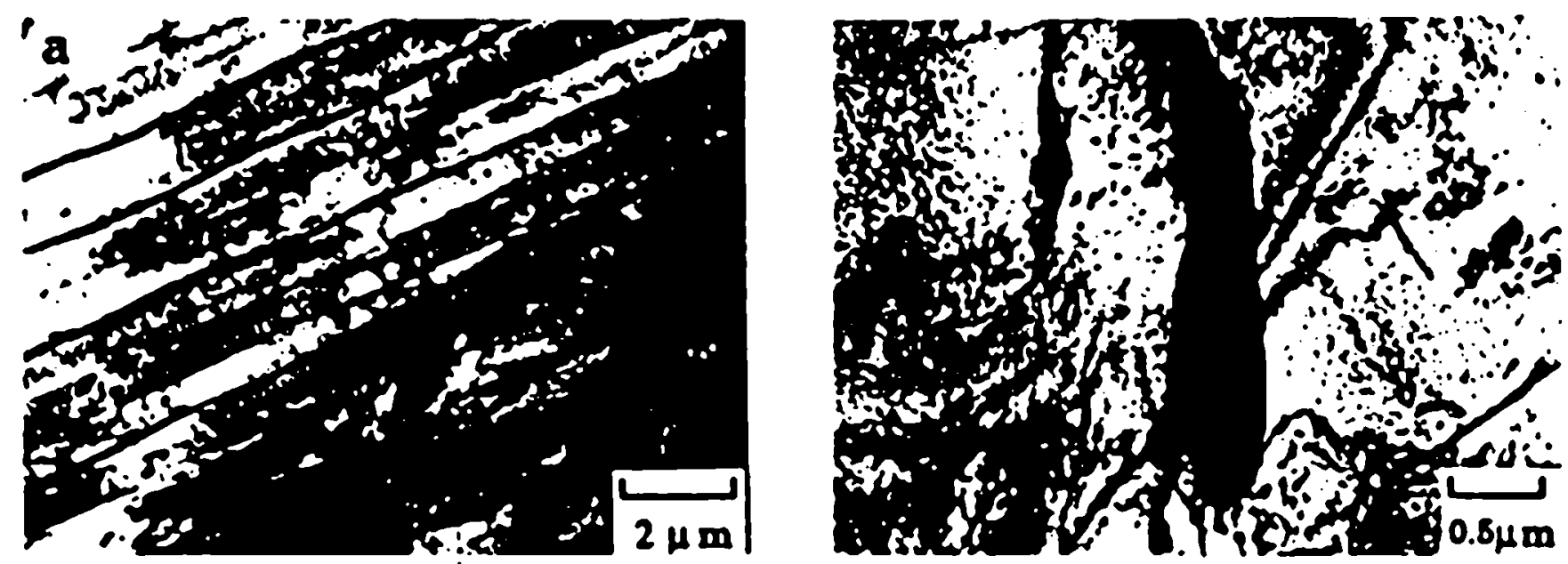

Fig. 2: M.A.C. aspect : a) Interlath particles of retained austenite in steel I ( $\Delta t=l 0 s)$ : b) partial decomposition of austenite into pearlite in steel VI (ot-300s).

As previously reported $(1,3,4)$, the M.A.C. constituent is composed essentially of elongated interlath particles in lath uppor balnite and of blocky pieces in acicular ferrite. It is notoworthy that this retained austenite (Y) is partially transformed into pearlite for the highest heat input (Fig. $2 b$ ), and into twinned martensite for the lowest welding energy. In accordance with these transformations, both $x$-ray diffractonetry and Mossbauer spectrometry (P1g. 3) Indicate that the austenite volume fraction evolves with $\Delta t$ between 2 and 8.5 (PIg. 4 and 5). The X-ray data arise from the ratio of the integrated 

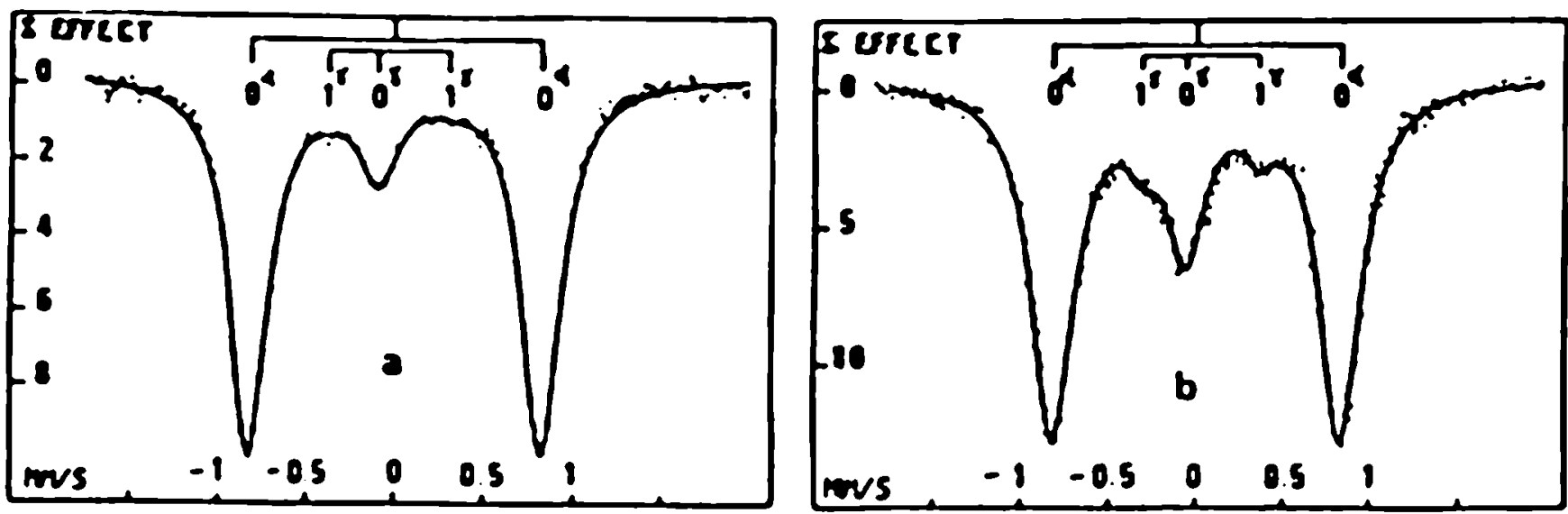

Pig. 3: Mossbauer spectra of alloy I cooled at al dt-10s: b) $\Delta t=100 s$.
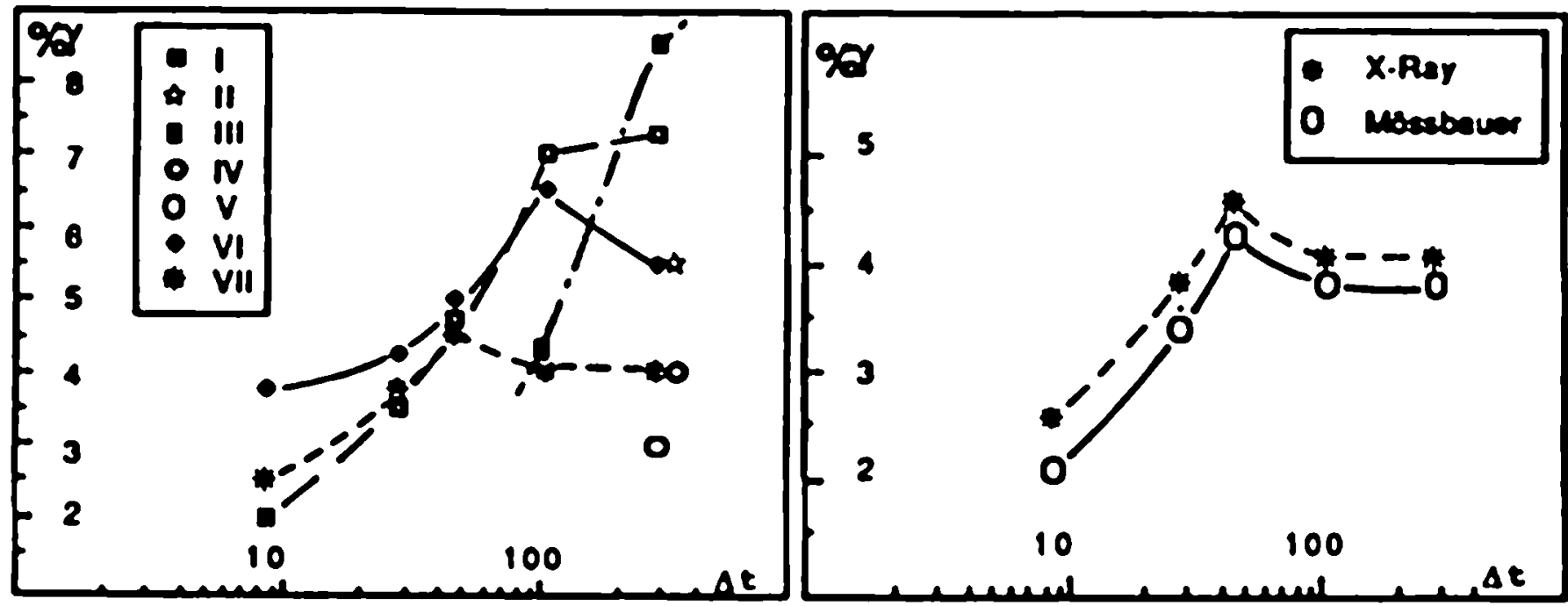

Plg. 4: X-ray cstimate of the retained austenlte content for the soven steols.
Fig. 5: Comparison of the X-ray and Mossbauer measurements of tho retalned austenite amount for steel VII

intensities of the (200) and (111) diffraction peaks (s). At the $=2 \mathrm{~m} \mathrm{~m}^{-1}$ speed range, the Hossbauer spectra display the two middle peaks of ferrite and three peaks of austenite corresponding to the or and Ir iron atoms surroundings (Pig. 3 ). The or and Ir surroundings are definod respectively by tho mlssing and by the presenco of one atom in the sphere of the iron nearest interstitlal nelghbours. The detalls of the Mossbaver spectra treatment can be found in reference (6). The integration of the austenite and ferrite (a) peaks areas over both $: 9 \mathrm{~mm} . \mathrm{s}^{-1}$ and $: 2 \mathrm{~m} \cdot \mathrm{s}^{-1}$ speed ranges lead to the texture-free Mossbauer estimate of the Y volume fraction. Plg. 5 shows that these Mossbauer values are very close but lower than the $x$-ray results. 
This sanll discrepancy may arlse both from the negloct of the sample thlckness oflect and from the uncertainty in the Lorentzlan peak deconvolution of the Mossbauer spectra. Moreover. it is worth emphasling that, In comparison with X-ray diffractometry. Mobsbauer spoctrometry has the advantage of moasuring the residual austenite carbon content $(1 \mathrm{C})$. Fig. 6 Indicates that $(\mathrm{C})$ is included between 0.2 and 0.7 Je and thus rather high according to tho mean alloy composition. This carbon level depends both on the autenite stabllity and on the welding cnergy. The S.T.E.M. E.D.X. epectra show that. regarding thelr contents In cubstitutional atoms (Mn. Tl and Sl), retained austenite and forrlto have the oame composition. $(1,4)$. The austenite stablilty 18 nevertholess achleved by the alloy chemletry that acts on 1 ts carbon onrlchment. Using a Hulegren extrapolation of the equllibrlum phase diagran. the carbon composteton of the stable austenito will be the higher. the lower is tho bainite transformation finishing temperature $(3,4)$. Furthermore, and as illustrated by the alloy VII case, tho residual austenite carbon content decroases during lts pearlitic destabliliation. Otherw180, as long as the austentte remalns undecomposed in a steel. $10 \mathrm{Ch}$ Incroases with dt, and thon with the diffusion time. In sumary. the evolutions show in Plg. 4. of the volume fraction of austente with at are explained by the competition between tho austenlte stabilization owing to its carbon enrichment, and 1 ts destabllization because of alloy composition.

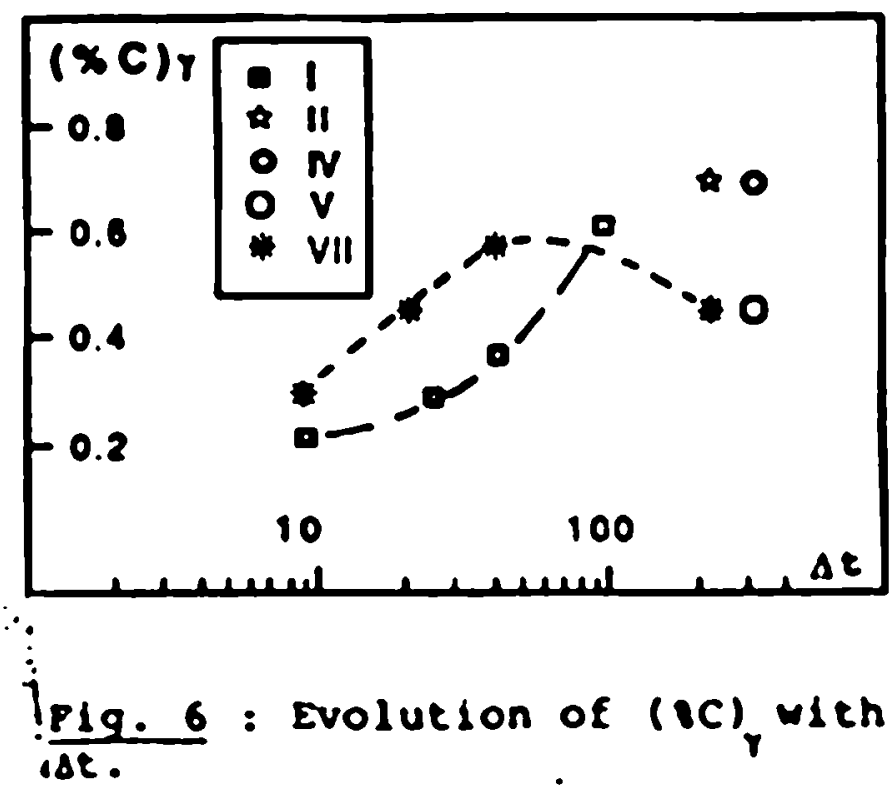

2. Effect of microstructure on H.A.2. toughness

Among the numerous parameters a priorl likoly to oporate on the toughnoss behavlour $(N$ interstitial content. prior austenite grain slze. preclpitation. types of microstructural constituents...l the nature of the ilcrostructure is the only one which exerts a signillcant influence in the present aterials (3.4). Plg. Ib displays the relationship botween $T_{K}$ and the major mlcrostructural constituents. The H.A.Z. toughnoss reduction with the welding energy has already boen corrolated with 
its alcrostructure evolution from martensite to lower balnlte and Inally to lath upper bainite (7). It is noteworthy that the same feature is observed in the present work with alloys I and III at at<SOs. In contrast, at higher $\Delta t$ values the toughness-microstructure correlation 18 less known. However, according to Plg.lb. lath upper bolnite structures exhlbit the worst resllience, whercas the toughness secms improved by the amount of aclcular ferrite. This feature can be explained by the effective grain size (De) concept of Naylor (8). Por Instance, the evaluation of Do in lath upper bainite and in aclcular ferrite leads to $7 \mathrm{~mm}$ and $3 \mathrm{um}$ in alloys II, IV and $V$. However, it should be noticed that tho previous interpretation 18 insulficient in order to understand the $T_{K}$ differences among the alloys at constant microstructure. The very harmful influence of residual austente on toughness must bo considered to overcome this difficulty. Fig. 7 shows that $T_{K}$ increases by $14 R / Y$ in a predominantly ferritic side plates structure (martensite and/or lath upper bainitel and only by $8 \mathrm{~K} / \mathrm{Y}$ in prevalence of aclcular ferrite. It 18 worth noting that thls detrimental influonce $18 \mathrm{higher}$ than the $8 \mathrm{~K} / \mathrm{M} . \mathrm{A} . \mathrm{C}$. I reported by Kasamatsu (7) for lath upper bainlelc structures. Moreover. Ikawa (9) has noticed that the detrinental effect of M.A.C. In alloyed steels is wre efficient for high than for slow cooling rates. Furthermore, as lliustrated by Fig. 8, retained austenlte promotes both initiation and propagation of the fracture. Those mechanical test data aro checked by numerous obsorvations of cavities at tho M.A.C. Interlaces (3) and by the crack route betwcen the cavlties. In tho same way. Chen (10) has demonstrated the predominant effect of M.A.C. On crack initiation.
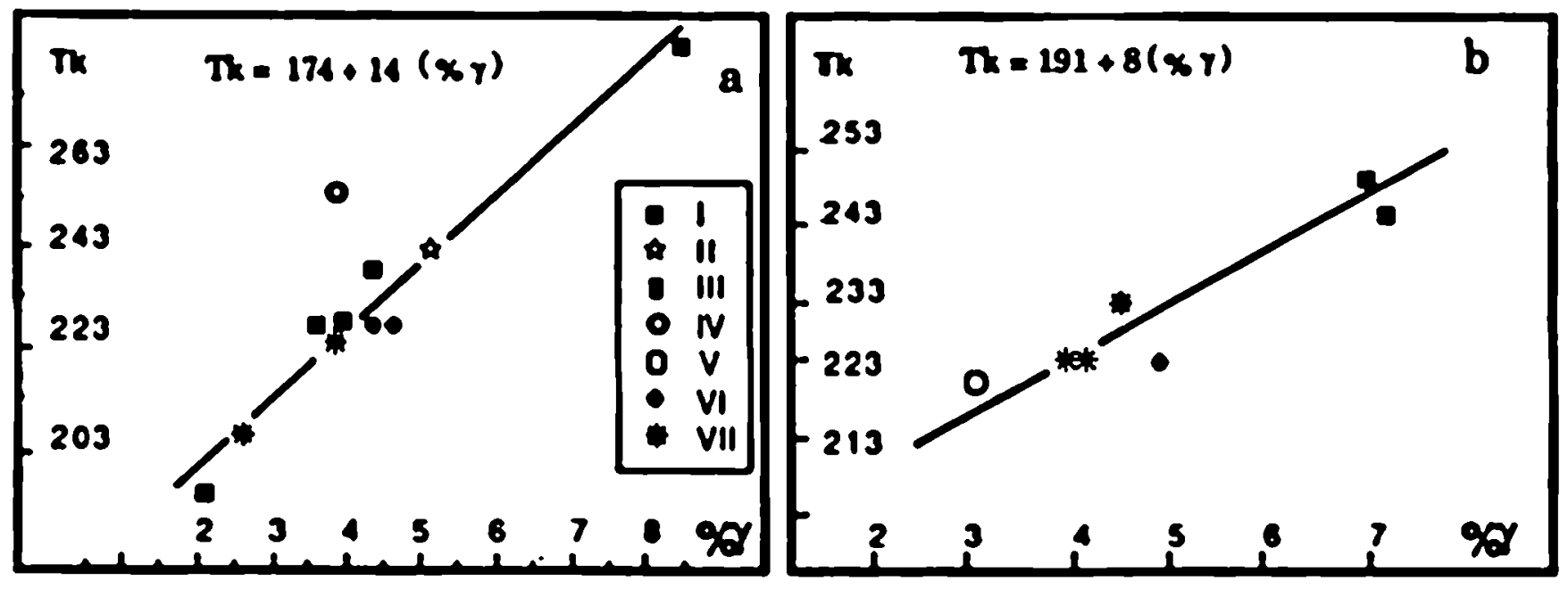

Pig. 7: Effect of retained austentice on $T_{K}$ : a) lath microstrucEure, b) aclcular microstructure.

otherwlse, according to Plg. 7a. the steel IV toughness 18 worse than lt can be expocted from 1 ts content in retalned austenite. This discrepancy can only be explained by the exletence of a signiflcant volume fraction of proeutectold ferrite (Tab. 2). The magnitude of the influence of a proeutoctold 
ferrite net in balnite seens to arlso fron the plasticlty varlation botween the softer allotrlomorph net and the harder grain interior. So, it is worth noting that this harmful effect of proeutectold ferrite is more marked in a ferrite oide plates structuro (ateel IV) than in acicular ferrite (steel yII) because of their respective hardness.

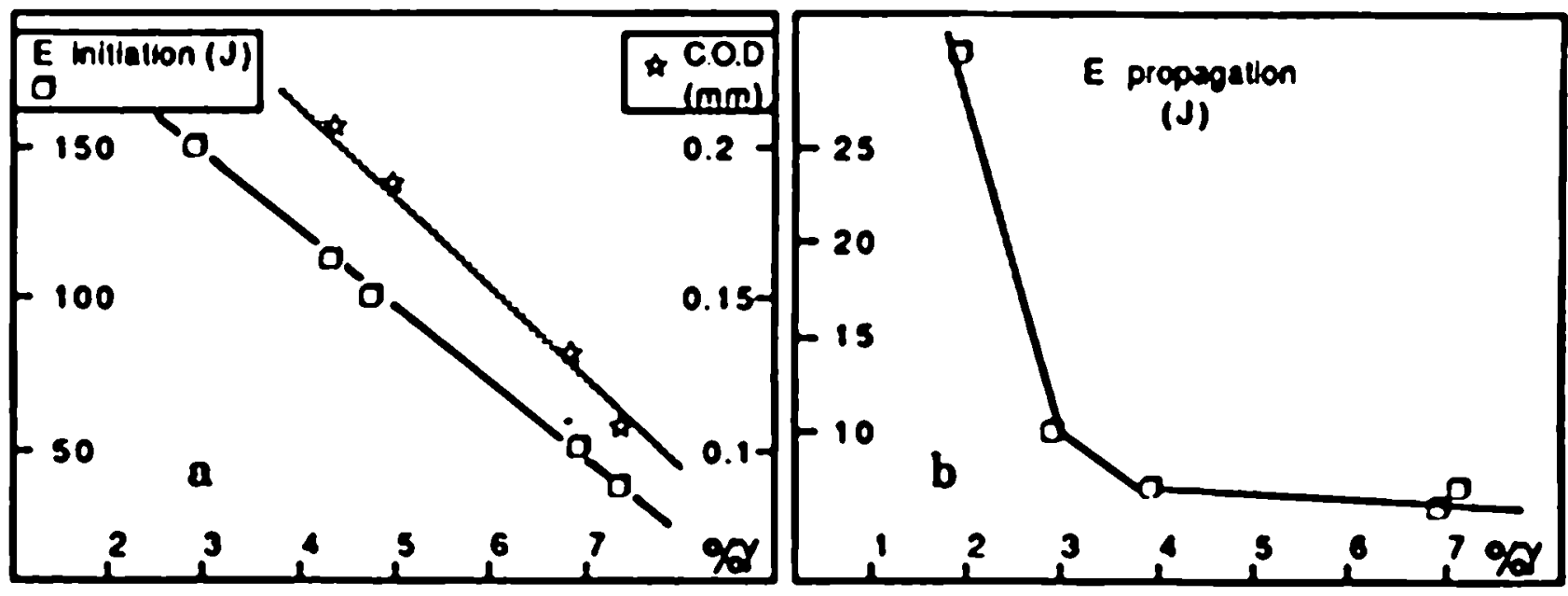

PIg. 8: Steel I tested at 243K. Unfavourable effect of $r$ on : a) tho eracture initiation (C.O.D. + Charpy V): b) the eracture propagation (Charpy $V$ data).

\section{Conclusion}

Mossbauer spectronetry and $x$-ray diffractometry show that the heat-affected zone of 0.1 we $C$ alcroalloyed steels can contain up to 8.5 in volume fraction of retained ausconite. This autenito content depends both on the steels chenical composition and on the welding cooling time. The uossbaver - estimated carbon lovol in austenito 18 monltored by the finishing bainite transformation temperature, the cooling time and the trend towards a porlitlc destabllization.

By comparison with the varlous parameters a priorl likely to act on toughness propertios, rosidual austenite exerts a significant and harmeul effect. The Charpy $v$ transition temperature Increases by $14 K / \mathrm{Y}$ and by $8 \mathrm{~K} / \mathrm{Y}$ respectively in a territic side platos and in an aclcular ferritic structure. The results of the mechanicall tests and of the metallographic observations show that residual austenlte prowotes both the crack nucleation and propagation.

Otherwise, at high heat inputs, the best II.A.2. toughness 18 achleved for an acicular ferritic structure. Moreover. a deleterlous influence of proeutectold ferrlte is noted when associated with lath upper bainite.

\section{Referencen}

(1) R. Talllard, T. Maurlckx, J. Foct: "EMAG" 1985, Instltute of Physics Conf. 78 (1985) 391. 
(2) T. Maurickx, R. Talliard: "High Nitrogen Steels" 88 , Institute of Metals, to be published.

(3) P. Verrler, T. Maurickx, R. Talliard, G. Garrigues: - Offshore Mechanics and Arctic Engineering" 1989. ASME. to be published.

(4) T. Maurlckx, Doctoral Thesis, Université de Lille I. (1987) n*411.

(5) P. Gulraldeng, vième Journée des Aclers Spéciaux, Soclété Prançalse de Métallurgle 1967.

(6) T. Maurickx, R. Taillard, J. Foct: C.R. Acad. Sc. Paris. 303 Serle II (1986) 41.

(7) Y. Rasamatsu, S. Takashima, T. Hosoya : J. Iron Steel Inst. Jap. 65 (1979) 92.

(8) J.P. Naylor, Doctoral Thesis, I.N.P. Lorralne, Nancy (1976) A.O. 12.278 .

(9) H. Ikawa, H. Oshige, T. Tanoue: Trans. Jap. Weld. Soc. $11(1980) 3$.

(10) J.H. Chen, Y. Kikuta, T. Araki, M. Yoneda, Y. Matsuda: Act. Met. 32 (1984) 1779. 